\title{
MIGRANT ENTREPRENEURSHIP IN A DIVERSE EUROPE: IN SEARCH OF SUSTAINABLE DEVELOPMENT
}

Tüzin Baycan-Levent

Department of Urban and Regional Planning

Istanbul Technical University

Istanbul

Turkey

Tuzin.baycanlevent@itu.edu.tr
Peter Nijkamp

Department of Spatial Economics

Free University

Amsterdam

The Netherlands

pnijkamp@feweb.vu.nl

\begin{abstract}
This paper aims to emphasize the importance of entrepreneurship for the European innovation system and addresses in particular the opportunities offered by migrant (or ethnic) entrepreneurship. After a concise review of the European 'entrepreneurial economy', the economic significance of self-employment is highlighted. It is argued that migrant entrepreneurship offers many possibilities for coping with socio-cultural diversity and may contribute to a sustainable socio-economic development. Several data are presented to support these views, while the paper also offers promising policy guidelines.
\end{abstract}




\section{Introduction: European Entrepreneurship}

The globalization trend in the past decades has prompted the emergence of an open space-economy, with a high degree of imports/exports of capital, labour, information and knowledge across the border. International migration and spatial mobility of firms exhibit a similar pattern. The last part of the twentieth century has witnessed a massive downsizing and drastic restructuring of many corporate firms. This new economic area, less based on the traditional inputs of natural resources, labour and capital, and more on the inputs of knowledge and ideas, is often labeled as the "entrepreneurial economy". This new age takes for granted the Schumpeterian ideas on risk-taking entrepreneurship as the basis for innovation and economic progress. Paradoxically, the increased degree of uncertainty creates also many opportunities for small and young firms, and hence leads to higher rates of entrepreneurship. Entrepreneurship affects the economy both directly and indirectly, and at various levels, through innovation, competition and restructuring (Wennekers and Thurik, 1999). Empirical investigations have shown that both a higher rate of new business start-ups and a higher rate of turbulence (the sum of start-ups and closures) enhance, after a certain time lag, economic growth and job creation (Carree and Thurik, 2003). Clearly, entrepreneurship is not only a driver for economic growth, competitiveness and job creation but also a vehicle for personal development and the resolution of social issues.

It should be noted that this change does not take place in all developed economies at the same time or to the same degree. In the early and mid twentieth century -until the early 1970's- a focus on entrepreneurship was largely absent on the European economic policy agenda. In the last part of the twentieth century, entrepreneurship re-emerged as a key agenda item of economic policy makers across Europe, both for specific nations as well as for the European Union as a whole (OECD, 1998; European Commission, 1999 and 2003; Uhlaner, 2003). With this increasing interest, expectations also rose regarding its potential as a source for job creation and economic growth. Today, SMEs and entrepreneurship are world-wide recognized as a key source of dynamism, innovation and flexibility. In Europe, they account for over $95 \%$ of enterprises, generate two-thirds of employment and are the main source of new jobs. In 2003, 99.8\% of enterprises in the enlarged EU were SMEs ( $<250$ employees) (OECD, 2005).

Traditionally, European entrepreneurship research is believed to lag behind that of the United States (Hauser, 2000; OECD, 2005; Uhlaner, 2003). Comparative evaluations, for example, on job destruction/creation in the US and Europe offer some empirical evidence and justify this belief. Hauser's comparative evaluation shows that over the last 15 years, Americans have destroyed about 35 million jobs, whereas Europeans have destroyed only 7.5 million jobs. However, over the same period the Americans created about 70 million new jobs, whilst Europeans managed to create only 6 million. The net effect is that Americans have created over 30 million jobs in 15 years and Europeans have destroyed 1.5 million (Hauser, 2000). Another comparative evaluation, by the International Migration Outlook 
(OECD, 2006), shows that between 1994 and 2004, net job creation was over 5 million in Spain, 2.5 million in France, 2.1 million in Italy, 1.9 million in the UK and 1.3 million in the Netherlands. In the United States, net job creation in the same period was over 15.5 million jobs. Today, the main issue for entrepreneurship in Europe is to close the gap with the Americans. To close this gap with the US, Hauser (2000) emphasizes the need for a change in attitudes along the following dimensions: (i) money, (ii) job destruction/creation, (iii) commercial exploitation, (iv) entrepreneurship, start-ups and risk, (v) control, (vi) failure, (vii) venture capital and corporate venturing.

Entrepreneurship in almost all member states of the European Union, as measured by harmonized rates of 'nascent entrepreneurship', is structurally lower than in a group of 'Anglo-Saxon' countries, including Canada, the USA, Australia and New Zealand (Global Entrepreneurship Monitor, 2002). The average ‘Total Entrepreneurial Activity’ or TEA index for all countries that participate in Global Entrepreneurship Monitor (GEM) is 9.4, whereas the average for the OECD-countries is 6.8 and the average for the EU-countries is 5.1. NewZealand, Australia, Iceland and the United States have the highest TEA rates of the OECD countries. The main reasons for Europe's arrear in entrepreneurship seems to be rooted in its culture and institutions (Audretsch et al., 2002; Bosma et al., 2002; Davidsson and Henrekson, 2002; Stel et al., 2003). Specifically, incentive structures in Europe are not conducive to entrepreneurship. Also, many European countries have relatively high legal and administrative barriers for business start-ups. Cultural and regulatory impediments in labour mobility and in knowledge transfer from universities to new businesses hamper entrepreneurship and innovation. Diversity seems to be one the feeble elements in the European 'entrepreneurial economy'.

On the other hand, it is recognized that entrepreneurship has a capacity to alleviate poverty, to increase employment opportunities and empower disadvantaged and underrepresented groups such as women and ethnic minorities. Indeed, entrepreneurship has been most pronounced among members of two different groups: immigrants and women. The increasing rate of business ownership among both immigrant groups and women has become one of the driving forces of the growth of national economies, in particular, in the US and in many countries in Europe (Barrett et al., 1996; Borjas, 1986 and 1990; Center for Women's Business Research, 2004 and 2005; Cross, 1992; GEM, 2004; Gorter et al., 1998; Kloosterman et al., 1998; OECD 2001a, 2001b and 2006; Weeks 2001; Pearce, 2005). Actually, both ethnic and female participation in terms of self-employment and entrepreneurship are seen as powerful economic forces and contributors to a solution to structural labour market problems in many industrialized countries. In the next section, we will address more in particular recent migration tendencies in Europe. 


\section{Migration in Europe: Past, Present and Future}

A number of factors, e.g., former colonial links, previous areas of labour recruitment, and ease of entry from neighbouring countries, is responsible for the trends in migration (Stalker, 2002). The diverse migrant flows can be classified into four broad categories of entry: labour migration, family reunification, undocumented workers or illegal immigrants, and asylum seekers. Since the end of World War II, Europe has had four main phases of immigration (Stalker, 2002; Zimmermann, 2005):

- Late 1940s and early-1950s - post-war adjustment, mass refugee flows and decolonisation: dramatic population shifts of around 15 million people who were forced to transfer from one country to another in order to relocate as a result of boundary changes, particularly between Germany, Poland, and the former Czechoslovakia. Over the same period, Great Britain, France, Belgium and the Netherlands were also affected by return migration and the inflow of workers from colonies.

- Early-1950s to 1973 - labour migration: the reconstruction of Europe and the average economic growth rate around 5 per cent per year created a huge demand for workers. Germany, Austria, Belgium, the Netherlands, Switzerland, Denmark and Sweden recruited unskilled workers from the Southern European countries. Over this period net immigration for Western Europe reached around 10 million.

- 1974 to mid-1980s - restrained migration: the oil shock of 1973 and increased social tensions and fears about recession led the governments all over Europe to close doors to further labour immigration and the main channels of immigration became family reunification and humanitarian immigration. However, new destinations including Italy, Greece, Portugal and Spain which were becoming more attractive to immigrants by their economic stimulus of joining the European Community emerged.

- Mid-1980s to 2000s - asylum seekers, refugees, and illegal immigrants: the period of political upheaval, particularly in Eastern Europe during and after the collapse of communism. From 1989-1998, more than 4 million people applied for asylum in Europe. With the increasing pressure of asylum seekers and tightening policies of governments more people tried to enter illegally. According to the cross-national data of the OECD and Eurostat, for Europe as a whole, the stock of illegal immigrants has been assumed to be between 2 and 3 million -accounting for 10 to 15 per cent of the total population of foreigners (IOM, 2000; Stalker, 2002).

An overall evaluation shows that Central Europe encompasses the traditionally attractive labour markets of Germany, Switzerland, Austria, the Benelux countries and France, whereas the Nordic welfare states, especially Denmark and Sweden, do not seem to encapsulate many typical labour markets. The most important European immigration countries, i.e., Germany and the Netherlands, have been traditionally the port of many labour migrants. After decades, since the 1980s, the Southern European countries like Italy, Greece, Spain and Portugal have 
also become traditional immigration countries, receiving people from Northern Africa, the Balkans, and Eastern Mediterranean, mostly through illegal immigration due to the proximity to these regions, the geography with long coastlines, numerous islands and mountainous regions at the borders which are easier to enter, and the situation that is seen as transit countries for people heading further north (Cavounidis, 2002; IOM, 2000; Lazaridis and Poyago-Theotoky, 1999; Stalker, 2002; Zimmermann, 2005).

The available data from OECD and Eurostat show the extent of migrant inflows during the 1990s and assigns to Germany the first place; the UK is next, though it follows a pattern with a steady overall rise; France shows a stable attractiveness over the years, whereas Italy exhibits a remarkable increase after 1998 and ranks as the third country in 1999 (Table 1). However, this picture has drastically changed in the 2000s, while Spain occupies the first place in 2004 with an inflow of 646000 foreign citizens; the UK still keeps its second rank and Germany is ranked as the third country. France continues to show its stable attractiveness at the forth place whereas the inflow to Italy has decreased in recent years and Italy is ranked as the fifth country (OECD, 2006).

Another trend in recent years is that migration flows have become more diverse. Although the main destination countries continue to receive the bulk of their immigrants from traditional sources, they are also seeing people arrive from a broader array of countries.

Table 1 Inflow of foreign citizens to selected countries, 1990-1999 (x1000) (Stalker 2002)

\begin{tabular}{lrrrrrrrrrr}
\hline & $\mathbf{1 9 9 0}$ & $\mathbf{1 9 9 1}$ & $\mathbf{1 9 9 2}$ & $\mathbf{1 9 9 3}$ & $\mathbf{1 9 9 4}$ & $\mathbf{1 9 9 5}$ & $\mathbf{1 9 9 6}$ & $\mathbf{1 9 9 7}$ & $\mathbf{1 9 9 8}$ & $\mathbf{1 9 9 9}$ \\
\hline Austria & - & - & - & - & - & - & - & 57 & - & - \\
Belgium & 51 & 54 & 55 & 53 & 56 & 53 & 52 & 49 & 51 & 58 \\
Denmark & 15 & 18 & 17 & 15 & 16 & 33 & 25 & 20 & 21 & - \\
Finland & 7 & 12 & 10 & 11 & 8 & 7 & 8 & 8 & 8 & 8 \\
France & 102 & 110 & 117 & 99 & 92 & 77 & 76 & 102 & 138 & 104 \\
Germany & 842 & 921 & 1208 & 987 & 774 & 788 & 708 & 615 & 606 & 674 \\
Greece & 10 & 14 & 10 & 18 & 15 & 18 & 20 & 17 & 35 & - \\
Hungary & 37 & 23 & 15 & 16 & 13 & 13 & 13 & 12 & 12 & 15 \\
Ireland & - & - & - & - & 13 & 14 & 22 & 24 & 21 & 22 \\
Italy & 97 & 71 & 59 & 51 & 53 & 68 & 143 & - & 111 & 268 \\
Luxembourg & 9 & 10 & 10 & 9 & 9 & 10 & 9 & 9 & 11 & 12 \\
Netherlands & 81 & 84 & 83 & 88 & 68 & 67 & 77 & 77 & 82 & 78 \\
Norway & 16 & 16 & 17 & 22 & 18 & 17 & 17 & 22 & 27 & 32 \\
Portugal & - & - & 14 & 10 & 6 & 5 & 4 & 3 & 7 & 11 \\
Sweden & 53 & 44 & 40 & 55 & 75 & 36 & 29 & 33 & 36 & 35 \\
Switzerland & 101 & 110 & 112 & 104 & 92 & 88 & 74 & 73 & 75 & 86 \\
UK & - & - & 204 & 190 & 194 & 206 & 216 & 237 & 258 & 277 \\
\hline
\end{tabular}

It is expected that in the future immigration to the EU is likely to increase, both as a result of the demand for labour and because of low birth rates in the EU. In the short and medium term many of these requirements are likely to be met by flows from Eastern Europe and the new member states (NMS), particularly following the eastward expansion of the EU (Boeri and Brücker, 2005; Stalker, 2002). The projections (Boeri and Brücker, 2005) show that the long-run migration stock is attained in 2030, 25 years after the introduction of the free 
movement, with a foreign population of 1.7 million persons in Germany and 3.0 million persons roughly in Europe (see Table 2). But, the longer-term picture will probably involve greater immigration from developing countries (Stalker, 2002).

Table 2 EU-15: potential migration from the eight NMS, 2004-2030 (Boeri and Brücker, 2005)

\begin{tabular}{lrrrrrrrrrr}
\hline & \multicolumn{1}{c}{ Net migration (thousand persons) } & \multicolumn{7}{c}{ Foreign population (thousand persons) } \\
\hline & $\mathbf{2 0 0 4}$ & $\mathbf{2 0 0 5}$ & $\mathbf{2 0 1 0}$ & $\mathbf{2 0 2 0}$ & $\mathbf{2 0 3 0}$ & $\mathbf{2 0 0 4}$ & $\mathbf{2 0 0 5}$ & $\mathbf{2 0 1 0}$ & $\mathbf{2 0 2 0}$ & $\mathbf{2 0 3 0}$ \\
\hline Austria & 20 & 22 & 9 & 2 & 1 & 81 & 102 & 173 & 207 & 219 \\
Belgium & 3 & 4 & 1 & 0 & 0 & 14 & 17 & 29 & 35 & 37 \\
Denmark & 3 & 3 & 1 & 0 & 0 & 12 & 15 & 25 & 30 & 32 \\
Finland & 3 & 4 & 2 & 0 & 0 & 14 & 18 & 30 & 36 & 38 \\
France & 13 & 14 & 6 & 1 & 1 & 53 & 67 & 114 & 136 & 144 \\
Germany & 156 & 169 & 68 & 13 & 7 & 628 & 797 & 1,345 & 1,608 & 1,705 \\
Greece & 18 & 20 & 8 & 2 & 1 & 73 & 93 & 157 & 188 & 199 \\
Ireland & 3 & 3 & 1 & 0 & 0 & 13 & 16 & 27 & 32 & 34 \\
Italy & 26 & 28 & 11 & 2 & 1 & 104 & 133 & 224 & 267 & 283 \\
Luxembourg & 0 & 0 & 0 & 0 & 0 & 2 & 2 & 3 & 4 & 4 \\
Netherlands & 4 & 5 & 2 & 0 & 0 & 18 & 23 & 38 & 46 & 49 \\
Portugal & 0 & 0 & 0 & 0 & 0 & 1 & 1 & 2 & 3 & 3 \\
Spain & 4 & 5 & 2 & 0 & 0 & 17 & 22 & 37 & 45 & 47 \\
Sweden & 6 & 7 & 3 & 1 & 0 & 25 & 32 & 53 & 64 & 67 \\
UK & 12 & 13 & 5 & 1 & 1 & 47 & 60 & 100 & 120 & 127 \\
EU-15 & 273 & 296 & 119 & 23 & 13 & 1,101 & 1,398 & 2,359 & 2,820 & 2,989 \\
\hline
\end{tabular}

Besides the evaluation of current trends in migration flows and projections for the future, the impact of migration in receiving and sending countries is another important issue in migration studies. The migration literature has addressed in particular the following questions from the perspective of economics: What is the impact of migration on welfare in the receiving and sending countries? Under which circumstances does the recipient or the sender lose or benefit from migration? Is migration a substitute or a complement for trade and capital flows?

The literature shows that the impact of migration on welfare in the receiving and sending countries depends heavily on the flexibility of labour markets. The labour market impact of migration has been examined in a large number of econometric studies in Europe. These studies rely on a cross-section of either regions or branches, and use variations in the migrant density in order to identify the impact of migration on wages and employment. The results of these studies show that migration is neutral for wages and employment of natives in the receiving countries (see for details Longhi et al., 2005, 2007).

On the other hand, as many studies show, migration provides many benefits and contributes to economic growth and the creation of new jobs. Economic growth and the creation of new jobs are strongly associated with the willingness to take up chances across regions and the supply of jobs regulates the flow of people seeking work. Regional labour mobility in the EU-15 is low -only about 1 out of 200 workers changes residence every year compared with 5 in the United States in spite of large income differentials within and across countries (Boeri and Brücker, 2005). Hence, immigration from outside the European Union 
has become a potentially very crucial role for the creation of a higher level of labour mobility in Europe. If there is labour mobility, it is largely due to international migration (Zimmermann, 2005). Europe is a place where migration is especially useful from an economic perspective. In the context of an ageing population and a need for certain skills, migrants make an important economic contribution. The recent study by Boeri and Brücker (2005) shows that international migration can significantly increase income per capita in Europe. They have estimated that at the given wage and productivity gap between Western and Eastern Europe, migration of 3\% of the Eastern population to the West could increase total EU GDP by up to $0.5 \%$. The contributions of migrants to the economic growth as well as to the creation of new jobs will be further examined in the next section.

In spite of a large potential gains from migration, migration policies are getting stricter all the time in Europe. Since 1990 there have been 92 reforms of national migration policies in the EU-15, that is, more than five reforms per year. However, the EU's migration policies are characterized by a fundamental paradox. While migration restrictions for non-EU countries are getting tighter, the legal and administrative barriers for migration within the Union have been reduced in the wake of the Single Market Programme. Boeri and Brücker (2005) offer two explanations for this paradox. One explanation is that Europe's policies serve the interests of the receiving country. According to this view, migration may entail significant direct and indirect costs. The direct costs include unemployment among natives. The indirect costs include higher taxes or social security contribution related to the payment of unemployment benefits and/or social transfers. Unemployed immigrants may also be associated with other indirect negative effects, they may become involved in survival-oriented illegal activities and become an easy target for organized crime. This view is also reflected in the results of some surveys at the EU level such as the European Social Survey ${ }^{1}$ and the Public Opinion Survey/Eurobarometer ${ }^{2}$, by perceptions of different groups for migration policies. While combining these two surveys, Boeri and Brücker (2005) have evaluated the nature and evolution over time of attitudes towards migrants in the EU-15. The results of their evaluation demonstrate that migration is perceived as a threat mainly among those with primary or lower educational attainments, low incomes and the prime-aged employees (Table 3).

The other explanation is that migrant policies have important cross-country spillovers. If one nation closes its borders to migrants, migration flows are diverted disproportionately to other nations, so the other nations react by closing their borders. As a result of this lack of coordination, all EU members can end up with migration restrictions that are higher than is

\footnotetext{
${ }^{1}$ The European Social Survey (ESS) is an academically-driven social survey designed to chart and explain the interaction between Europe's changing institutions and the attitudes, beliefs and behaviour patterns of its diverse population. ESS was first carried out in 2002-2003 in 22 countries of the EU and contains a large section (about 50 questions) on attitudes towards migrants.

${ }^{2}$ The Eurobarometer is a public opinion survey carried out by Gallup for the European Commission since 1970, involving the members of the EU at any date and including at broadly three-year intervals a number of questions on migration.
} 
Table 3 The role of personal characteristics in shaping preferences for migration policies (Boeri and Brücker, 2005)

\begin{tabular}{|c|c|c|c|c|c|c|}
\hline & \multicolumn{3}{|c|}{ Eurobarometer, 2000} & \multicolumn{3}{|c|}{ European Social Survey, 2002} \\
\hline & $\begin{array}{c}\text { Too } \\
\text { many }\end{array}$ & $\begin{array}{c}\text { Increase } \\
\text { unemployment }^{\mathbf{b}}\end{array}$ & $\begin{array}{c}\text { Abuse } \\
\text { welfare }^{c}\end{array}$ & $\begin{array}{c}\text { Take jobs } \\
\text { awayd }\end{array}$ & $\begin{array}{c}\text { Bad for } \\
\text { economy }\end{array}$ & $\begin{array}{c}\text { Fiscal } \\
\text { burden }\end{array}$ \\
\hline Male & & & & & - & - \\
\hline $15-24$ & - & - & - & - & & - \\
\hline $25-34$ & & & - & + & ++ & \\
\hline $55-64$ & & & & & & + \\
\hline Over 65 & & & & & & ++ \\
\hline Head of the household & & & ++ & & & \\
\hline Low education & ++ & + & & ++ & ++ & ++ \\
\hline High education & - & - & - & - & - & - \\
\hline Left-wing & - & - & - & - & - & - \\
\hline Right-wing & ++ & ++ & ++ & ++ & ++ & ++ \\
\hline Christian & . & . & . & & & \\
\hline Employed & & & ++ & & + & \\
\hline Self-employed & & & & & & + \\
\hline Retired & ++ & ++ & ++ & & & \\
\hline Income & - & & - & - & - & \\
\hline $\begin{array}{l}\% \text { of variance explained } \\
\text { by country dummies }\end{array}$ & 4.1 & 4.1 & 2.1 & 10.2 & 2.1 & 10.0 \\
\hline
\end{tabular}

Questions: ${ }^{\mathrm{a}}$ Speaking generally about people from minority groups in term of race, religion or culture, do you think there are not many or too many of them living in your country?

${ }^{\mathrm{b}}$ The presence of people of these minority groups increases unemployment in your country?

${ }^{\mathrm{c}}$ People of these minority groups abuse the system of social benefits?

${ }^{\mathrm{d}}$ Would you say that people who come to live here generally take jobs away from workers in your country, or generally help to create new jobs?

${ }^{\mathrm{e}}$ Most people who come to live here work and pay taxes. They also use health and welfare services. On balance, do you think people who come here take out more than they put in or put in more than they take out?

${ }^{f}$ Would you say it is generally bad or good for your country's economy that people come to live here from other countries?

collectively optimal. Boeri and Brücker (2005) argue that the bill paid by Europe for the lack of coordination of migration policies is high.

From the perspective of migration policy, Zimmermann (2005) has defined 6 migration challenges to draw attention to the determinants and the consequences of these movements in Europe:

1. Unskilled migration: If current trends prevail, unskilled migration may cause unemployment among immigrants and unskilled native workers and may lead to more social and economic disruptions.

2. Migration of the most skilled in the labour force: There is an increasing excess demand for skilled labour and the upcoming needs cannot be satisfied sufficiently by the local labour force, however, Europe has no standing on the international labour markets for high-skilled people.

3. Global impact of migration on the economy: It is required productive mix of skilled and unskilled workers, however, it is increasingly observed that the lack of qualified workers decreases the incentives to hire low-skilled workers. If Europe fails to train enough people or to attract high-skilled labour, there will be soon a pressing need to develop markets that supply jobs for unskilled labour. 
4. Factor mobility: If people do not move or not allowed to move, trade or capital mobility may take its place. Virtual migration is the ultimate threat: many jobs can be exercised through the internet. European jobs may thus melt away without any real movement in the foreign work force.

5. Expansion of the European Union: Expansion will trigger further immigration and create new market opportunities in Central and Eastern Europe. As the inflow of low-skilled people has already taken place through illegal immigration, now, the EU countries need to ensure that the mobile high-skilled East Europeans are not attracted by the traditional immigration countries.

6. Unavailable migrants for the labour market: A large part of the migrants did not come as economic migrants but through family reunification and as asylum-seekers who cannot work initially and are missing incentives to work. This is a policy failure.

Zimmermann has emphasized that the EU will soon have to decide how to meet these challenges in an organized, systematic and collaborative way. He suggests a selective policy that discourages unskilled migrants and attracts skilled foreign workers will vitalize the labour market, foster growth and increase demand for unskilled native workers. He also suggests to develop a joint European legal framework that guides the individual countries migration policy activities and to set European-wide quotas for net immigration on a permanent and temporary level.

However, it should be noticed that the coordination of migration policy in terms of a selective quota that will allow only skilled workers from the new EU countries to migrate to Western countries would be favourable for Western countries, but harmful for the new Eastern countries, and especially for the low skilled workers of these countries. Therefore, immigration quota should be accompanied with support to the financing of local safety nets preventing the most disadvantaged individuals in the sending countries from falling into extreme poverty.

Obviously, in order to develop an appropriate policy, it is necessary to learn more about how immigrants currently fare in European countries, how they affect the economy and how policy measures have contributed to the current migration situation.

\section{Migrant Entrepreneurship in Europe}

Entrepreneurship is a source of sustainable socio-economic development. The main feature of economic restructuring in the last decades has been a marked shift from employment in large firms to self-employment in small firms. This trend has been most pronounced among members of two different groups: immigrants and women. The increasing rate of business ownership among both immigrant groups and women has become one of the driving forces of the growth of national economies, in particular, in the US and in many countries in Europe (Barrett et al., 1996; Borjas, 1986 and 1990; Center for Women’s 
Business Research, 2004 and 2005; Cross, 1992; GEM, 2004; Gorter et al., 1998; Kloosterman et al., 1998; OECD, 2001a, 2001b and 2006; Weeks, 2001; Pearce, 2005). Actually, both ethnic and female participation in terms of self-employment and entrepreneurship are seen as powerful economic forces and contributors to a solution to structural labour market problems in many industrialized countries.

The studies focused on migrant entrepreneurship started preponderantly in the USA (Light, 1972), whereas later studies on this topic also emerged across Western Europe (Ward and Jenkins, 1984) in the United Kingdom and France (Simon, 1993) and in Israel (Razin, 1993). These studies recognized the significant share of migrants in small and medium-sized enterprises. However, researches on migrant entrepreneurship in Europe lag behind researches in the US (Le, 1999). Recent papers in the rising literature on this issue in Europe and the US, and other immigration countries include Baycan-Levent et al. (2003 and 2006), CEEDR (2000), Chaganti and Green (2002), Delft et al. (2000), Fairlie (2004 and 2005), Masurel et al. (2002 and 2004), Rath (2000), Rettab (2001) and Zhou (2004).

The increasing number of self-employed migrants and the results of many studies show that the tendency or ability to become self-employed differs between native people and immigrants (Borjas, 1986; Fairlie and Meyer, 1996; Verheul et al, 2001). In general, immigrants are more likely to be self-employed than similarly skilled native-born workers, while self-employment rates of immigrants exceed in many countries those of native-born. While assimilation has a positive impact on self-employment probabilities (Borjas, 1986), the level of education and time since immigration are important determinants of self-employment (Fairlie and Meyer, 1996).

Since the early 1980s, self-employment among migrant groups has increased significantly in Europe and migrant entrepreneurship has become an important topic in the EU, with a great impact on micro, meso and macro levels of development. The booming economy in Europe and the available opportunities in various market niches appear to have led to the emergence of a new breed of migrant entrepreneurs. The migrant groups in Europe as well as the business ownership among these groups are expected to continue to grow. It is generally found that contemporary migrant communities generate entrepreneurs who are able to contribute more and more to the economic growth and the welfare of the host countries (Rettab, 2001). Migrant entrepreneurs make a variety of contributions to the economic environment of their host and home countries. At the micro-level, migrant entrepreneurs help to satisfy a variety of needs and demands for both migrant and non-migrant consumers. More entrepreneurship is not only desirable and attractive, but also unavoidable. The most important reason is that because of globalization and increasing competition there is an enforced tendency towards more flexible job relations in the business.

Although the importance of migrant entrepreneurship for Europe is recognized by scholars and policy makers and there is a remarkable literature on the issue, the data and information on migrant entrepreneurship are far from being comparable and very limited at 
the EU level. Most studies address a specific migrant group in a city with a small sample in general and there is a huge gap in evaluating migrant entrepreneurship at both the country and the EU level across different migrant groups. However, the limited comparable data and information provided by OECD show some interesting features of the phenomenon, exhibit the current migrant entrepreneurship trends and offer a quantitative picture of migrant entrepreneurship in Europe.

According to the 'International Migration Outlook' published by OECD (2006), immigrants account for a large proportion of the total labour force in the OECD countries (Table 4). The numbers have increased by over $10 \%$ over the past five years (1999-2004) in almost all OECD countries. While the increase is especially large in Southern European countries -for instance, 6 times in Italy and 3.5 times in Spain-, the increase reached levels of $46 \%$ in Ireland, $42 \%$ in Sweden and $30 \%$ in the US. In 2004, foreign-born labour force accounted for $45 \%$ of total labour force in Luxembourg, 25\% in Switzerland, $13 \%$ in Sweden, $12 \%$ in Germany and 11\% in Belgium, France, the Netherlands and Spain. Due to the current demographic trends and the characteristics of recent immigrants (a younger age structure than that of the native population), the increase in immigrants share in the labour force can be expected to continue and to grow.

Table 4 Foreign and foreign-born labour force in selected OECD countries, 1999-2004 thousands and percentages (OECD, 2006)

\begin{tabular}{|c|c|c|c|c|c|c|}
\hline & \multicolumn{3}{|c|}{ Foreign-born labour force } & \multicolumn{3}{|c|}{ Foreign labour force } \\
\hline & 1999 & 2004 & \multirow{2}{*}{$\begin{array}{c}\text { \% of total } \\
\text { labour force }\end{array}$} & 1999 & 2004 & \multirow{2}{*}{$\begin{array}{c}\% \text { of total } \\
\text { labour force }\end{array}$} \\
\hline & \multicolumn{2}{|c|}{ Thousands } & & \multicolumn{2}{|c|}{ Thousands } & \\
\hline Austria & 470 & 585 & 15.3 & 367 & 320 & 8.4 \\
\hline Belgium & 450 & 512 & 11.5 & 380 & 357 & 8.0 \\
\hline Denmark & 133 & 161 & 5.9 & 97 & 107 & 3.9 \\
\hline France & 3013 & 2987 & 11.3 & 1587 & 1444 & 5.4 \\
\hline Germany & 4241 & 4800 & 12.2 & 3446 & 3539 & 9.0 \\
\hline Greece & 284 & 402 & 8.5 & 171 & 303 & 6.4 \\
\hline Ireland & 129 & 188 & 10.0 & 57 & 112 & 5.9 \\
\hline Italy & 213 & 1350 & 5.6 & 224 & 759 & 3.2 \\
\hline Luxembourg & 73 & 88 & 45.0 & 75 & 88 & 45.0 \\
\hline Netherlands & 684 & 929 & 11.1 & 268 & 299 & 3.6 \\
\hline Norway & 124 & 167 & 7.1 & 68 & 88 & 3.8 \\
\hline Portugal & 230 & 379 & 7.3 & 64 & 150 & 2.9 \\
\hline Spain & 645 & 2241 & 11.2 & 359 & 1852 & 9.3 \\
\hline Sweden & 428 & 606 & 13.3 & 179 & 204 & 4.5 \\
\hline Switzerland & & 1022 & 25.3 & 805 & 889 & 22.0 \\
\hline UK & 2293 & 2759 & 9.6 & 1116 & 1557 & 5.4 \\
\hline
\end{tabular}

When sectoral breakdown of immigrant employment is examined, it is seen that immigrant employment is spreading to the service sectors (Table 5). Over $75 \%$ of immigrants are employed in services, not including public administration and extraterritorial organizations, in the UK, Norway and Sweden, but the figure is over $60 \%$ in almost all countries. Immigrants are generally over-represented in the construction, hotel and restaurant sectors, and also in the healthcare and social services sectors. However, the sectoral 
Table 5 Employment of foreign-born by sector, 2003-2004 average (OECD, 2006)

\begin{tabular}{|c|c|c|c|c|c|c|c|c|c|c|}
\hline \multicolumn{11}{|c|}{ Percentage of total foreign-born employment } \\
\hline & $\begin{array}{l}\text { Agriculture } \\
\text { and fishing }\end{array}$ & $\begin{array}{c}\text { Mining, } \\
\text { manufacturing } \\
\text { and energy }\end{array}$ & Construction & $\begin{array}{c}\text { Wholesale } \\
\text { and retail } \\
\text { trade }\end{array}$ & $\begin{array}{l}\text { Hotels and } \\
\text { restaurants }\end{array}$ & Education & $\begin{array}{l}\text { Health and } \\
\text { other } \\
\text { community } \\
\text { services } \\
\end{array}$ & Households & $\begin{array}{c}\text { Admin. } \\
\text { and ETO }\end{array}$ & $\begin{array}{c}\text { Other } \\
\text { services }\end{array}$ \\
\hline Austria & 1.2 & 22.3 & 8.8 & 14.4 & 12.0 & 4.2 & 8.8 & 0.4 & 2.9 & 25.0 \\
\hline Belgium & 1.2 & 17.3 & 6.9 & 13.6 & 7.4 & 6.2 & 10.7 & 0.6 & 9.1 & 27.1 \\
\hline Finland &.. & 20.1 & 5.1 & 14.5 & 8.9 & 6.8 & 13.6 &.. &.. & 26.9 \\
\hline France & 1.9 & 14.6 & 10.3 & 11.9 & 5.9 & 6.0 & 9.7 & 5.8 & 6.8 & 27.2 \\
\hline Germany & 1.3 & 32.0 & 6.4 & 12.9 & 7.6 & 3.9 & 10.1 & 0.7 & 3.3 & 21.9 \\
\hline Greece & 6.1 & 16.3 & 27.3 & 11.4 & 9.2 & 2.7 & 2.4 & 13.4 & 1.4 & 9.7 \\
\hline Ireland & 2.2 & 16.6 & 8.4 & 11.5 & 13.2 & 6.4 & 12.5 &.. & 2.9 & 25.4 \\
\hline Luxembourg & 1.0 & 10.5 & 16.0 & 12.2 & 6.0 & 1.9 & 6.3 & 4.2 & 12.2 & 29.8 \\
\hline Netherlands & 1.5 & 20.4 & 4.5 & 15.0 & 8.2 & 5.4 & 12.2 &.. & 4.6 & 28.2 \\
\hline Norway &.. & 13.7 & 4.5 & 12.6 & 8.6 & 8.0 & 20.7 & .. & 3.7 & 27.0 \\
\hline Spain & 6.0 & 13.6 & 16.3 & 12.2 & 12.0 & 3.6 & 3.7 & 12.2 & 2.0 & 18.5 \\
\hline Sweden & 0.6 & 17.2 & 2.7 & 12.1 & 6.6 & 10.8 & 18.6 &.. & 3.9 & 27.5 \\
\hline Switzerland & 1.1 & 19.7 & 8.4 & 15.2 & 7.3 & 6.1 & 13.4 & 1.3 & 3.4 & 24.1 \\
\hline UK & 0.4 & 11.8 & 4.3 & 13.6 & 9.0 & 8.4 & 14.5 & 1.0 & 5.2 & 31.9 \\
\hline
\end{tabular}


breakdown varies considerably from one country to another. For example, 6\% of immigrants work in agriculture in Spain, 32\% work in the mining and manufacturing industries in Germany, $27 \%$ are in construction in Greece, $15 \%$ in the wholesale and retail trade in Switzerland, $13 \%$ in hotels and restaurants in Ireland and $21 \%$ in health care and social services in Sweden. Immigrant employment in education and health is becoming increasingly significant in a number of countries. Between $20 \%$ and $30 \%$ of immigrants work in one of these two sectors in Finland, Switzerland, Sweden and the UK (OECD, 2006).

The International Migration Outlook states also that there was a relatively sharp increase in employment in several OECD countries and immigrants have contributed to job creations in many countries (Table 6). Net job creation were over 5 million in Spain, 2.5 million in France, 2.1 million in Italy, 1.9 million in the UK and 1.3 million in the Netherlands. In the United States, net job creation over the period was over 15.5 million jobs, of which 9 million are occupied by persons born abroad. Immigrants contributed to and benefited from over $30 \%$ of net job creation in the UK, whereas the percentage was $20 \%$ in Spain, the Netherlands, Portugal, Italy and Sweden. According to another report, 'Global Entrepreneurship Monitor United Kingdom' (GEM, 2004), UK ethnic minorities lead on entrepreneurship. The report states that the UK forms Europe's most entrepreneurial economy and that people from ethnic minorities make a large and important contribution to the success of the UK economy.

Table 6 Employment change in some OECD countries, total and foreign-born, 1994-2004 (OECD, 2006)

\begin{tabular}{|c|c|c|c|c|c|c|c|c|}
\hline & \multicolumn{4}{|c|}{ Employment (thousands) } & \multicolumn{2}{|c|}{$\begin{array}{c}\text { Relative change } \\
\text { over the period (\%) }\end{array}$} & \multicolumn{2}{|c|}{$\begin{array}{c}\text { Increase in employment } \\
\text { (thousands) }\end{array}$} \\
\hline & \multicolumn{2}{|c|}{ Foreign-born } & \multicolumn{2}{|c|}{ Total } & \multirow[b]{2}{*}{$\begin{array}{l}\text { Foreign- } \\
\text { born }\end{array}$} & \multirow[b]{2}{*}{$\begin{array}{l}\text { Total } \\
\text { employment }\end{array}$} & \multirow[b]{2}{*}{$\begin{array}{l}\text { Foreign- } \\
\text { born }\end{array}$} & \multirow[b]{2}{*}{ Total } \\
\hline & $\begin{array}{c}\text { Average } \\
1994-1995\end{array}$ & $\begin{array}{c}\text { Average } \\
\text { 2003-2004 }\end{array}$ & $\begin{array}{c}\text { Average } \\
\text { 1994-1995 }\end{array}$ & $\begin{array}{c}\text { Average } \\
\text { 2003-2004 }\end{array}$ & & & & \\
\hline Australia & 1876 & 2336 & 7879 & 9385 & 24.5 & 19.1 & 460 & 1506 \\
\hline Austria & 424 & 494 & 3630 & 3645 & 16.5 & 0.4 & 70 & 15 \\
\hline Belgium & 310 & 423 & 3748 & 4074 & 36.6 & 8.7 & 113 & 326 \\
\hline Canada & 2007 & 2343 & 12636 & 14352 & 16.8 & 13.6 & 336 & 1716 \\
\hline Denmark & 79 & 141 & 2501 & 2636 & 79.5 & 5.4 & 62 & 135 \\
\hline Finland & 1 & 55 & 1994 & 2374 & 7611.4 & 19.0 & 54 & 380 \\
\hline France & 2337 & 2474 & 21616 & 24065 & 5.9 & 11.3 & 137 & 2449 \\
\hline Germany & 4199 & 4038 & 37593 & 35273 & -3.8 & -6.2 & -161 & -2320 \\
\hline Greece & 144 & 335 & 3676 & 4223 & 132.6 & 14.9 & 191 & 546 \\
\hline Ireland & 66 & 175 & 1203 & 1780 & 163.8 & 48.0 & 109 & 577 \\
\hline Italy & 125 & 527 & 19764 & 21892 & 322.4 & 10.8 & 402 & 2128 \\
\hline Luxembourg & 64 & 81 & 162 & 186 & 26.0 & 15.0 & 17 & 24 \\
\hline Netherlands & 505 & 829 & 6687 & 8028 & 64.3 & 20.0 & 324 & 1341 \\
\hline Norway & 88 & 151 & 2007 & 2229 & 71.9 & 11.1 & 63 & 222 \\
\hline Portugal & 170 & 330 & 4227 & 4800 & 94.6 & 13.5 & 160 & 572 \\
\hline Spain & 273 & 1752 & 12221 & 17441 & 541.6 & 42.7 & 1479 & 5220 \\
\hline Sweden & 227 & 525 & 3981 & 4260 & 131.0 & 7.0 & 298 & 279 \\
\hline UK & 1796 & 2503 & 25397 & 27304 & 39.4 & 7.5 & 707 & 1907 \\
\hline US & 10831 & 20142 & 116801 & 132499 & 86.0 & 13.4 & 9311 & 15698 \\
\hline
\end{tabular}

Self-employment among immigrants has also increased in almost all OECD countries over the past five years in both numbers and as a percentage of overall self-employment (Table 7). The share of foreign-born in total self-employment accounted for $38.7 \%$ in Luxembourg, 17.5\% in Switzerland, nearly 14\% in Sweden, and 12\% in Belgium in 2004. 
Although all these figures draw attention to the increase in migrant employment and selfemployment and show the improvements in the labour market situation of immigrants in absolute terms, a comparison with native population shows a different picture, a deterioration in the labour market situation of immigrants. According to the figures, the immigrant participation rate was generally lower than that of nationals (Table 8). The participation rate was 30 points lower than that of native population in Poland whereas 20 and 10 points lower respectively in Denmark and the Netherlands in 2003-2004. Although the immigrant participation rate has increased in the majority of countries over the past 10 years, this increase was often more slow than the rate for the native population. For example, in the Netherlands, nearly $42 \%$ of immigrants were unemployed in 1994, compared to $34 \%$ in 2004 , a reduction of 7.8 percentage points. At the same time, the participation rate for the native population rose by 8.2 points to $78.2 \%$ in 2004 . Although immigrant participation in the labour market improved in absolute terms, the situation in relation to the native population deteriorated slightly. Similar observations may be made concerning Austria, Belgium, Ireland and France (OECD, 2006).

Table 7 Foreign-born in self employment in some OECD Countries, 1999-2004, percentages (OECD, 2006)

\begin{tabular}{lcccc}
\hline & $\begin{array}{c}\text { Share of foreign-born in total } \\
\text { self-employment }\end{array}$ & \multicolumn{2}{c}{$\begin{array}{c}\text { Share of self-employment in total } \\
\text { foreign-born employment }\end{array}$} \\
\hline & $\mathbf{1 9 9 9}$ & $\mathbf{2 0 0 4}$ & $\mathbf{1 9 9 9}$ & $\mathbf{2 0 0 4}$ \\
\hline Austria & 6.0 & 9.2 & 3.9 & 7.6 \\
Belgium & 10.0 & 12.4 & 7.6 & 15.2 \\
Denmark & 5.2 & 8.4 & 12.0 & 9.7 \\
France & 10.4 & 11.2 & 5.2 & 10.4 \\
Germany & 9.2 & 10.3 & 4.0 & 9.2 \\
Greece & 1.9 & 2.6 & 7.2 & 9.7 \\
Ireland & 7.5 & 8.0 & 11.0 & 14.2 \\
Luxembourg & 31.7 & 38.7 & 4.2 & 6.9 \\
Netherlands & 7.2 & 8.7 & 5.1 & 9.8 \\
Norway & 6.1 & 8.0 & 6.1 & 8.4 \\
Portugal & 2.8 & 3.8 & 10.5 & 13.8 \\
Spain & 2.7 & 4.5 & 10.5 & 12.5 \\
Sweden & 9.9 & 13.7 & 6.4 & 10.3 \\
Switzerland &. & 17.5 &.. & 15.0 \\
UK & 10.2 & 10.9 & 8.3 & \\
\hline
\end{tabular}

On the other hand, immigrants and foreigners are often more exposed to unemployment than the native population or nationals. In 2003-2004, immigrants in the majority of European OECD countries were relatively harder hit by unemployment than was the native population (Table 8). The share of foreigners in unemployment is the highest in the Netherlands, but it is also significant in Denmark and Belgium. The rate of unemployment in Denmark and Belgium is at least double that of the native population. Immigrants are also relatively more exposed to long-term unemployment than are natives in approximately half of the countries.

In some OECD countries, certain groups of immigrants such as women, young people and elderly workers face specific difficulties in entering the labour market. For example, 
Table 8 Labour market situation of foreigners and nationals in selected OECD countries, 1995, 2000 and 2003-2004 (OECD, 2006)

\begin{tabular}{|c|c|c|c|c|c|c|c|c|c|c|c|c|c|c|c|c|c|c|c|c|c|c|c|c|}
\hline & \multicolumn{8}{|c|}{ Participation rate (\%) } & \multicolumn{8}{|c|}{ Unemployment rate (\%) } & \multicolumn{8}{|c|}{ Employment/population ratio (\%) } \\
\hline & \multicolumn{4}{|c|}{ Nationals } & \multicolumn{4}{|c|}{ Foreigners } & \multicolumn{4}{|c|}{ Nationals } & \multicolumn{4}{|c|}{ Foreigners } & \multicolumn{4}{|c|}{ Nationals } & \multicolumn{4}{|c|}{ Foreigners } \\
\hline & 1995 & 2000 & 2003 & 2004 & 1995 & 2000 & 2003 & 2004 & 1995 & 2000 & 2003 & 2004 & 1995 & 2000 & 2003 & 2004 & 1995 & 2000 & 2003 & 2004 & 1995 & 2000 & 2003 & 2004 \\
\hline Austria & 71.1 & 70.9 & 71.4 & 70.4 & 75.5 & 74.7 & 74.0 & 68.6 & 4.1 & 4.3 & 4.4 & 4.5 & 6.8 & 8.8 & 8.3 & 11.5 & 68.2 & 67.9 & 68.2 & 67.2 & 70.4 & 68.2 & 67.8 & 60.6 \\
\hline Belgium & 62.8 & 66.0 & 65.1 & 65.8 & 54.8 & 58.3 & 55.6 & 59.8 & 8.2 & 5.8 & 6.9 & 6.7 & 23.5 & 15.6 & 18.2 & 15.9 & 57.7 & 62.1 & 60.6 & 61.4 & 42.0 & 49.2 & 45.5 & 50.3 \\
\hline Czech Rep. & .. & 71.2 & 70.2 & 69.9 & .. & 73.0 & 69.6 & 70.6 & .. & 8.8 & 7.5 & 8.3 & .. & 7.3 & 10.2 & 5.6 & .. & 64.9 & 64.9 & 64.1 & .. & 67.6 & 62.5 & 66.6 \\
\hline Denmark & 79.9 & 80.3 & 79.3 & 79.8 & 51.4 & 52.6 & 51.7 & 53.6 & 7.5 & 4.0 & 4.1 & 5.1 & 24.2 & 10.6 & 9.2 & 12.1 & 74.0 & 77.1 & 76.0 & 75.8 & 39.0 & 47.0 & 47.0 & 47.1 \\
\hline Finland & 72.2 & 76.8 & 76.9 & 76.4 & 61.9 & 72.9 & 71.5 & 69.8 & 17.1 & 11.0 & 10.4 & 10.2 & 26.3 & 29.0 & 18.3 & 25.6 & 59.9 & 68.4 & 68.9 & 68.6 & 45.6 & 51.8 & 58.4 & 52.0 \\
\hline France & 68.0 & 69.2 & 69.8 & 69.8 & 62.3 & 63.0 & 63.3 & 64.8 & 11.3 & 9.6 & 8.5 & 9.2 & 21.7 & 20.9 & 18.8 & 18.5 & 60.3 & 62.6 & 63.9 & 63.4 & 48.8 & 49.8 & 51.4 & 52.8 \\
\hline Germany & 71.0 & 71.7 & 72.8 & 72.9 & 66.2 & 64.3 & 65.2 & 64.3 & 7.5 & 7.5 & 9.2 & 10.1 & 15.1 & 12.9 & 16.7 & 18.0 & 65.6 & 66.3 & 66.1 & 65.5 & 56.3 & 56.0 & 54.4 & 52.8 \\
\hline Greece & 60.0 & 62.7 & 63.3 & 66.1 & 70.2 & 71.8 & 73.4 & 72.9 & 9.2 & 11.3 & 9.1 & 10.4 & 13.8 & 11.6 & 8.8 & 9.3 & 54.4 & 55.6 & 57.5 & 59.2 & 60.5 & 63.5 & 66.9 & 66.1 \\
\hline Hungary & .. & .. & 60.6 & 60.1 & .. & .. & 61.6 & 64.8 & .. & .. & 5.8 & 5.9 & .. & .. & .. & .. & .. & .. & 57.0 & 56.6 & .. & .. & 58.1 & 62.7 \\
\hline Ireland & 61.7 & 67.6 & 68.3 & 68.8 & 58.2 & 64.4 & 65.3 & 64.8 & 12.0 & 4.3 & 4.4 & 4.4 & 18.1 & 6.4 & 6.5 & 6.8 & 54.3 & 64.6 & 65.3 & 65.7 & 47.7 & 60.2 & 61.0 & 60.4 \\
\hline Italy & 57.3 & .. & .. & .. & 66.7 & .. & .. & .. & 11.9 & .. & .. & .. & 12.9 & .. & .. & .. & 50.4 & .. & .. & .. & 58.1 & .. & .. & .. \\
\hline Luxembourg & 57.2 & 62.6 & 61.0 & 61.6 & 65.9 & 66.7 & 70.9 & 68.9 & 2.5 & 1.6 & 2.4 & 3.0 & 3.6 & 3.4 & 5.2 & 7.0 & 55.7 & 61.6 & 59.6 & 59.8 & 63.5 & 64.4 & 67.2 & 64.1 \\
\hline Netherlands & 70.1 & 75.8 & 77.1 & 77.4 & 53.1 & 58.1 & 62.2 & 60.5 & 6.5 & 2.6 & 3.4 & 4.4 & 23.6 & 7.2 & 9.5 & 10.0 & 65.5 & 73.8 & 74.5 & 73.9 & 40.6 & 53.9 & 56.3 & 54.5 \\
\hline Norway & .. & 80.8 & 79.2 & 78.9 & .. & 75.5 & 71.9 & 73.4 & .. & 3.4 & 4.1 & 4.1 & 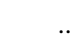 & .. & 10.1 & 10.7 & . & 78.1 & 76.0 & 75.7 & .. & 71.8 & 64.7 & 65.5 \\
\hline Portugal & 67.5 & 71.1 & 72.7 & 72.7 & 49.9 & 74.7 & 79.6 & 75.6 & 7.3 & 3.9 & 6.4 & 6.6 & .. & - & 11.2 & 13.3 & 62.6 & 68.3 & 68.1 & 68.0 & 43.8 & 68.3 & 70.7 & 65.6 \\
\hline Slovak Rep. & .. & 69.6 & 69.8 & 69.7 & .. & .. & 82.4 & 83.6 & .. & 19.1 & 17.1 & 18.6 & .. & .. & .. & .. & .. & 56.3 & 57.8 & 56.7 & .. & .. & - & .. \\
\hline Spain & 59.4 & 65.0 & 66.7 & 67.8 & 65.9 & 70.7 & 76.9 & 77.6 & 22.9 & 13.9 & 11.0 & 10.9 & 22.8 & 15.5 & 14.8 & 13.4 & 45.8 & 56.0 & 59.4 & 60.4 & 50.8 & 59.8 & 65.5 & 67.2 \\
\hline Sweden & 81.0 & 76.2 & 78.5 & 78.3 & 64.7 & 61.7 & 67.4 & 68.1 & 7.7 & 5.1 & 5.3 & 6.3 & 19.7 & 14.6 & 13.2 & 16.2 & 74.7 & 72.3 & 74.4 & 73.3 & 52.0 & 52.7 & 58.5 & 57.1 \\
\hline Switzerland & .. & 81.1 & 81.6 & 81.4 & .. & 78.3 & 79.7 & 79.3 & .. & 1.9 & 2.9 & 3.1 & .. & 5.6 & 8.8 & 8.9 & .. & 79.6 & 79.2 & 78.9 & .. & 74.0 & 72.7 & 72.2 \\
\hline UK & 75.1 & 76.1 & 75.9 & 75.4 & 65.0 & 65.4 & 67.1 & 67.7 & 8.6 & 5.4 & 4.7 & 4.5 & 14.4 & 10.0 & 7.9 & 7.5 & 68.7 & 71.9 & 72.3 & 72.1 & 55.6 & 58.9 & 61.8 & 62.6 \\
\hline
\end{tabular}

Note: “..” means not available and “-“ means non significative at B threshold. 
young people born abroad are significantly more exposed to unemployment than are their native counterparts in the majority of OECD countries. In France, while unemployment among young people born in that country is nearly $20 \%$, the figure for young immigrants is $35 \%$. In Belgium and Sweden unemployment among young immigrants is at least twice that of the native population. On the other hand, foreign-born women have lower employment rates than their native-born counterparts in almost all countries under consideration. The differences between native and immigrant women increase with the level of education. Highly qualified immigrant women from non-OECD member countries are particularly disadvantaged. In Germany, for example, the employment rate of this group is only 43\% compared to $60 \%$ for all highly qualified immigrant women and $81 \%$ for native-born women with the same level of education. Similar results hold for most receiving countries, in particular for Switzerland, Luxembourg and the Nordic countries, where the gap with the natives reaches $20 \%$ or more.

An overall evaluation shows that immigrants represent a large and growing share of the labour force in the majority of European countries, especially in the services sector. Immigrants contribute to job creations in many countries with their increasing share in selfemployment. They are undoubtedly a promising source of socio-economic sustainability. However, their participation rate in the labour market is on the whole lower than that of the native population, certain categories of immigrant labour force, women, young people and elderly workers, face with specific difficulties in entering labour market, they are often more exposed to unemployment, long-term unemployment than the native population. As a result, the progress is significant but still not sufficient to reduce the disparities.

\section{Concluding remarks}

Europe is facing an age of immigration. Today, immigrants represent a large and growing share of the labour force in the majority of European countries and they contribute to job creations in many countries with their increasing share in self-employment. However, their participation rate in the labour market is on the whole lower than that of the native population, certain categories of immigrant labour force - women, young people and elderly workers face specific difficulties in entering labour market, and they are often more exposed to unemployment than the native population. Therefore, high unemployment rates, low participation rates and low status are the main determinants that push immigrants to become entrepreneur in many European countries, especially cities.

From a policy perspective, today, the EU is faced with many challenges stemming from new migration trends as well as labour market structures. These challenges need to be met in an organized, systematic and collaborative way. Against the strategy of "Fortress Europe”, a joint European legal framework in order to coordinate migration policy, a European-wide quota for net immigration and a selective policy are discussed widely by scholars and policy makers and occupies the current policy agenda of the EU. However, in order to develop an 
appropriate policy, it is necessary to learn more about how immigrants currently live in European countries, how they affect the economy and how policy measures have contributed to the current migration situation. Future research focussed on comparative evaluation at the European level would be very helpful in this respect, with particular emphasis on the drivers of socio-economic behaviour and on the critical success factors for economic performance. More insight into migrant entrepreneurship is needed as this new phenomenon in Europe is a potentially important source of sustainable growth.

\section{References}

Andersson, P., E. Wadensjö (2004a) Self-Employed Immigrants in Denmark and Sweden: A Way to Economic Self-Reliance? Forschungsinstitut zur Zukunft der Arbeit Institute for the Study of Labor. Discussion Paper Series. IZA DP No. 1130.

Andersson, P., E. Wadensjö (2004b) Why Do Self-Employed Immigrants in Denmark and Sweden Have Such Low Incomes? Forschungsinstitut zur Zukunft der Arbeit Institute for the Study of Labor. Discussion Paper Series. IZA DP No. 1280.

Audretsch, D.B., A.R. Thurik, I. Verheul, A.R.M. Wennekers (Eds) (2002) Entrepreneurship: Determinants and Policy in a European-US Comparison. Kluwer Academic Publishers.

Barrett, G.A., T.P. Jones, D. McEvoy (1996) Ethnic Minority Business: Theoretical Discourse in Britain and North America. Urban Studies 33(4-5): 783-809.

Baycan Levent, T., E. Masurel, P. Nijkamp (2003). Diversity in entrepreneurship: ethnic and female roles in urban economic life. International Journal of Social Economics 30(11): 1131-1161.

Baycan Levent, T., E. Masurel, P. Nijkamp (2006). Gender differences in ethnic entrepreneurship. International Journal of Entrepreneurship and Innovation Management 6(3): 173-190.

Boeri, T., H. Brücker (2005) Why are Europeans so tough on migrants? Economic Policy 20(44): 629-703.

Borjas, G.J. (1986) The Self-Employment Experience of Immigrants. The Journal of Human Resources. 21(4): 485-506.

Borjas, G.J. (1990) Friends or Strangers: The Impact of Immigrants on the US Economy. Basic Books, New York.

Borooah, V.K., M. Hart (1999) Factors Affecting Self-Employment among Indian and Black Caribbean Men in Britain. Small Business Economics 13: 111-29.

Bosma, N., H. Stigter, S. Wennekers (2002) The Long Road to the Entrepreneurial Society;Global Entrepreneurship Monitor 2001 The Netherlands. EIM, Zoetermeer.

Carree, M.A., A.R. Thurik (2003) The Impact of Entrepreneurship on Economic Growth. In: Z.J. Acs and D.B. Audretsch (Eds) Handbook of Entrepreneurship Research. Kluwer Academic Publisher.

Cavounidis, J. (2002) Migration in Southern Europe and the Case of Greece. International Migration 40(1): 4570.

CEEDR (2000) Young Entrepreneurs, Women Entrepreneurs, Ethnic Minority Entrepreneurs and CoEntrepreneurs in the European Union and Central and Eastern Europe. Final Report to the European Commission, DG Enterprise, Centre for Enterprise and Economic Development Research (CEEDR) Middlesex University Business School, UK.

Center for Women's Business Research (2004) Business Owned by Women of Color in the United States, 2004: A Fact Sheet. http://www.womensbusinessresearch.org

Center for Women's Business Research (2005) Top Facts About Women-Owned Businesses. http://www.womensbusinessresearch.org/topfacts.html

Chaganti R, P.G. Greene (2002) Who are ethnic entrepreneurs? A study of entrepreneurs' ethnic involvement and business characteristics. Journal of Small Business Management (40): 126-143.

Constant, A., K.F. Zimmermann (2004) Self-Employment Dynamics Across the Business Cycle: Migrants Versus Natives. Forschungsinstitut zur Zukunft der Arbeit Institute for the Study of Labor. Discussion Paper Series. IZA DP No. 1386.

Cross, M. (Ed) (1992) Ethnic Minorities and Industrial Change in Europe and North America. Cambridge University Press, Cambridge.

Delft, H. van, C. Gorter, P. Nijkamp (2000) In search of ethnic entrepreneurship opportunities in the city: A comparative policy study. Environment and Planning C: Government and Policy 18(4): 429-451.

European Commission (1999) Action Plan to Promote Entrepreneurship and Competitiveness. Directorate General for Enterprise. 
European Commission (2003) Green Paper: Entrepreneurship in Europe. Directorate General for Enterprise.

Eurostat (2003) Eurostat Yearbook: The Statistical Guide to Europe. Luxembourg: OOPEC

Fairlie R W. (2004) Recent Trends in Ethnic and Racial Business Ownership. Small Business Economics 23: 203-218

Fairlie, R.W. (2005) Entrepreneurship among Disadvantaged Groups: An Analysis of the Dynamics of SelfEmployment by Gender, Race, and Education. In: S.C. Parker, Z.J. Acs, D.R. Audretsch (Eds) Handbook of Entrepreneurship. Kluwer Academic Publisher (forthcoming).

Fairlie, R.W., B.D. Meyer (1996) Ethnic and Racial Self-Employment Differences and Possible Explanations. The Journal of Human Resources 31(4): 757-793.

GEM (2004) Global Entrepreneurship Monitor United Kingdom. Rebecca Harding, London Business School.

Gorter, C., P. Nijkamp, J. Poot (eds) (1998) Crossing Borders. Ashgate, Aldershot.

Hatziprokopiou, P. (2004) Balkan Immigrants in the Greek City of Thessaloniki: Local Processes of Incorporation in an International Perspective. European Urban and Regional Studies 11(4): 321-38.

Hauser, H. (2000) Entrepreneurship in Europe. Business Strategy Review 11(1): 1-9.

IOM (2000) World Migration Report. International Organization for Migration, Geneva.

Kloosterman, R.C., J. van der Leun, J. Rath (1998) Across the Border; Economic Opportunities, Social Capital and Informal Businesses Activities of Immigrants. Journal of Ethnic Migration Studies 24: 367-376.

Kloosterman, R., J. van der Leun, J. Rath (2002) Mixed Embeddedness: (In)formal Economic Activities and Immigrant Businesses in the Netherlands. International Journal of Urban and Regional Research 26(3): 25266.

Lazaridis, G., J. Poyago-Theotoky (1999) Undocumented Migrants in Greece: Issues of Regularization. International Migration 37(4): 715-740.

Light, I. (1972) Ethnic Enterprises in America. University of California Press, Berkeley.

Longhi, S., P. Nijkamp, J. Poot (2005), A Meta-Analytic Assessment of the Effect of Immigration on Wages, Journal of Economic Surveys, 19(3): 451-477.

Longhi, S., P. Nijkamp, J. Poot (2007), The Fallacy of Job Robbing, Journal of Migration and Refugee Issues, 1(4): 131-152.

Masurel E, Nijkamp P, Tastan M, Vindigni G, (2002). Motivations and Performance Conditions for Ethnic Entrepreneurship. Growth \& Change. 33(2): 238-260.

Masurel, E., P. Nijkamp, G. Vindigni (2004) Breeding Places for Ethnic Entrepreneurs: A Comparative Marketing Approach. Entrepreneurship and Regional Development. 16(2): 77-86.

Mingione, E. (2002) Introduction: Immigrants and the Informal Economy in European Cities. International Journal of Urban and Regional Research 26(3): 209-11.

OECD (1998) Fostering Entrepreneurship, the OECD Jobs Strategy. OECD: Paris

OECD (2001a) Second OECD Conference on Women Entrepreneurs in SMEs: Realising the Benefits of Globalisation and the Knowledge-Based Economy. OECD Proceedings.

OECD (2001b) Issues Related to Statistics on Women's Entrepreneurship. Workshop on Firm-Level Statistics, 26-27 November, 2001. DSTI/EAS/IND/SWP/AH(2001)11.

OECD (2005) SME and Entrepreneurship Outlook. OECD: Paris

OECD (2006) International Migration Outlook. SOPEMI 2006 Edition, OECD: Paris

Oliveira, C.R. (2003) Immigrants' Entrepreneurial Opportunities: The Case of the Chinese in Portugal. The Fondazione Eni Enrico Mattei Nota Di Lavoro 75.2003.

Pearce, S.C. (2005) Today's Immigrant Woman Entrepreneur. Immigration Policy in Focus 4(1): 1-17.

Quassoli, F. (2002) Migrants in the Italian Underground Economy. International Journal of Urban and Regional Research 26(3): 212-31.

Ram, M., T. Jones, T. Abbas, B. Sanghera (2002) Ethnic Minority Enterprise in its Urban Context: South Asian Restaurants in Birmingham. International Journal of Urban and Regional Research 26(1): 24-40.

Rath J, (2000) Introduction: immigrant business and the economic, politico-institutional and social environment. In: J Rath (Ed) Immigrant Business: The Economic, Political and Social Environment. Macmillan Press, London.

Razin, E. (1993) Immigrant Entrepreneurs in Israel, Canada and California. In: I. Light and P. Bhachu (Eds) Immigration and Entrepreneurship, Culture, Capital, and Ethnic Networks. London: Transaction Publishers.

Rettab B, (2001) The Emergence of Ethnic Entrepreneurship - A Conceptual Framework. EIM/Business \& Policy Research, Zoetermeer

Sasse, G., E. Thielemann (2005) A Research Agenda for the Study of Migrants and Minorities in Europe. Journal of Common Market Studies 43(4): 655-671.

Simon, G. (1993) Immigrant Entrepreneurs in France. In: I. Light and P. Bhachu (Eds) Immigration and Entrepreneurship. Culture, Capital and Ethnic Networks. London: Transaction Publishers.

Stalker, P. (2002) Migration Trends and Migration Policy in Europe. International Migration 40(5): 151-179. 
Uhlaner, L.M. (2003) Trends in European Research on Entrepreneurship at the Turn of the Century. Small Business Economics 21(4): 321-328.

UNHCR (2003) Statistical Yearbook: Trends in Displacement, Protection and Solutions. Geneva: United Nations High Commissioner for Refugees

Verheul, I., P.Risseeuw, G. Bartelse (2001) Gender differences in strategy and human resource management. Rotterdam Institute for Business Economic Studies 2001/3.

Weeks, J.R. (2001) The Face of Women Entrepreneurs: What We Know Today. Second OECD Conference on Women Entrepreneurs in SMEs: Realising the Benefits of Globalisation and the Knowledge-Based Economy. OECD Proceedings.

Wennekers, S., R. Thurik (1999) Linking Entrepreneurship and Economic Growth. Small Business Economics 13: $27-55$.

Zimmermann, K.F. (2005) European Labour Mobility: Challenges and Potentials. De Economist 153(4): 425450.

Zhou, M. (2004) Revisiting Ethnic Entrepreneurship: Convergencies, Controversies, and Conceptual Advancements. The International Migration Review 38(3): 1040.

Zorlu, A., J. Hartog (2001) Migration and Immigrants: The Case of the Netherlands. Tinbergen Institute Discussion Paper TI 2001-042/3 